\title{
FINE STRUCTURE OF GILLS AND SKINS OF THE AMPHIBIOUS MUDSKIPPER, PERIOPHTHALMUS CHRYSOSPILOS BLEEKER, 1852, AND A NON-AMPHIBIOUS GOBY, FAVONIGOBIUS REICHEI (BLEEKER, 1853)
}

\author{
MAZLAN Abd. Ghaffar*, MASITAH Amzal, MAHANI Mansor-Clyde \\ School of Environmental Studies and Natural Resource Sciences, Faculty of Science and Technology, \\ Universiti Kebangsaan Malaysia, Bangi Selangor D.E., Malaysia
}

\begin{abstract}
Mazlan A.G., Masitah A., Mahani M.-C. 2006. Fine structure of gills and skins of the amphibious mudskipper, Periophthalmus chrysospilos Bleeker, 1852, and a non-amphibious goby, Favonigobius reichei (Bleeker, 1853). Acta Ichthyol. Piscat. 36 (2): 127-133.
\end{abstract}

Background. Periophthalmus chrysospilos and Favonigobius reichei are most abundant gobies species (Family: Gobiidae) inhabiting estuaries in the west coast of Peninsular Malaysia. Thirty-six goby species are amphibious: the rest remain in water, like other teleosts. However, information on the fine structure of gills and skins of these gobies species that may help to understand their functions in air breathing is still lacking. This study was aimed at describing fine structure of the gills and skins of these two co-existing species of gobies living in the terrestrial and aquatic environment.

Materials and Methods. Fifty-six specimens of amphibious (Periophthalmus chrysospilos) and 67 specimens of nonamphibious gobies (Favonigobius reichei) were collected from estuary. Gills and skins were dissected out and samples were treated following the standard electron microscopy sample preparation. Samples were affixed onto specimen stubs with silver paint and then coated with a thin layer of gold using a BIO-RAD-SC500 ion sputter. All samples were viewed using SEM Series XL 30, Philips.

Results. P. chrysospilos possesses short, thick, bent and twisted gill filaments whereas the F. reichei has long, thin, and straight filaments. There were differences in shapes and numbers of the secondary lamellae attached to the filaments in $P$. chrysospilos and F. reichei. The skin of $F$. reichei also has a significant difference in architectural build-up compared to $P$. chrysospilos. The functional adaptation on the use of gills and skins in $P$. chrysospilos and F. reichei in natural environment are discussed.

Conclusions. The gills of $P$. chrysospilos show some unique features (i.e. low density of secondary lamellae and smaller gill rakers) that can be used to explain the animal's ability to successfully live out of water in comparison to $F$. reichei that are more adapted to aquatic life like other teleosts. Special architectural plan of gills and skins of both goby species may have contributed to their existence in the estuary area.

Keywords: fish, goby, mudskipper, Periophthalmus chrysospilos, Favonigobius reichei, (Papillogobius reichei), gills, skin, electron microscopy

\section{INTRODUCTION}

Gobies are fishes of the Gobiidae family, inhabiting saltwater, brackishwater, and freshwater of tropical and subtropical ocean. According to Nelson (1994), the family comprises 1875 species in 212 genera. Thirty-six goby species are amphibious (Murdy 1989, Lee et al. 1995, Murdy and Takita 1999, Takita et al. 1999) and those are commonly referred to as mudskippers. Whilst most gobies remain in water, like other teleosts relying on gas exchange through gills, some of them capable of air-breathing (aquatic air-breathers) and are commonly found coexisting with the amphibious mudskippers. The occur- rence of the air-breathers is usually limited to tidal pools. The gill of teleost fishes is well suited for water breathing, but upon air exposure the lamellae coalesce, greatly reducing the functional exchange surface (Low et al. 1993, Wilson et al. 1999). Yet, some fishes have the ability to breathe air effectively. Air breathing among fishes is associated with modification of the gill and the development of accessory breathing organs (ABO) (Sayer 2005).

Several studies reported that amphibious fishes breathe air using both gills and skin (Hughes and Morgan 1973, Whitear 1986, Al-Kadhomity and Hughes 1988, Low et. al. 1988, Yokoya and Tamura 1992, Suzuki 1992, Zhang et

\footnotetext{
${ }^{*}$ Correspondence: Dr Mazlan Abd Ghaffar, Head of Marine Science Programme, Pusat Sains Sekitaran dan Sumber Alam, Fakulti Sains dan Teknologi, Universiti Kebangsaan Malaysia, 43600 UKM Bangi Selangor D.E., Malaysia, phone: +60389213219 , fax:+60389253357, E-mail: mag@pkrisc.cc.ukm.my ormagfish05@yahoo.com
} 
al. 2000, Park and Lee 2002, Park 2002). It is predicted that differences in fine structural morphology of the gills and skins of mudskipper with the non-amphibious gobies are important surviving factors in the menacing habitat of the estuary area. Information on the fine structure of gill and skin of gobies, that may help to understand their functions in air breathing, is still lacking. The present paper investigates the fine structure of the gills and skins of two co-existing species of gobies, the amphibious mudskipper (P. chrysospilos) and non-amphibious goby (F. reichei) collected from the Sepang estuary, Peninsular Malaysia.

\section{MATERIAL AND METHODS}

Field collection of specimens. Fifty-six specimens of amphibious gobies $(2.17-5.20 \mathrm{~cm}$ standard length (SL); $0.16-2.70 \mathrm{~g}$ body wet weight) and 67 specimens of nonamphibious gobies (4.20-7.42 cm SL; 1.43-7 .81 g body wet weight) were collected using hand-nets during low tides in Sepang estuary, Selangor, Malaysia. These gobiid species are abundant and successfully surviving in two different environments in the estuary. The non-amphibious gobiid species are commonly found in the mud flat pool during low tides whilst the amphibious species on the other hand are common goby species living on land in the study areas. All the specimens caught were placed in small polystyrene containers and kept alive in aerated seawater prior to further analysis in the university laboratory. Taxonomic identification and confirmation of the species were based on description given in Murdy (1989) and Kottelat et al. (1993). The amphibious goby was identified as Periophthalmus chrysospilos Bleeker, 1852 and non-amphibious goby was identified as Favonigobius reichei (Bleeker, 1853).

Laboratory preparation of samples for electron microscopy observation. Each fish was anaesthetized in fully-aerated seawater containing $0.1-0.3 \mathrm{ml} \cdot \mathrm{L}^{-1}$ of 2-phenoxy-ethanol (Sigma) for 5-10 min before it was killed; gills and skins were dissected under the dissecting microscope. Samples were washed with $0.85 \%$ sodium chloride solution, and immersed in $4 \%$ formalin made of $50 \%$ filtered seawater. After one day in $4 \%$ formalin solution, each sample was dehydrated through a graded ethanol solution series: $50 \%, 70 \%, 80 \%, 85 \%, 90 \%, 95 \%$, and $100 \%$. These samples were critical-point-dried with carbon dioxide. Samples were affixed onto specimen stubs with silver paint and then coated with a thin layer of gold using a BIORAD Microscience Division SC 500 ion sputter. All samples were viewed under a scanning electron microscope (SEM Series-XL 30 Philips).

Legal and ethical issues: All field sampling and laboratory protocols followed and complied with in the current laws of Malaysia.

\section{RESULTS}

Preliminary observations of gill structure were performed under the light microscope to elucidate basic architectural plan of all gill structures between Periophthalmus chrysospilos and Favonigobius reichei. This helps to facilitate precision dissection on the gill structures for electron microscopy sample preparation. The fine-structure examination on the electron micrographs showed that $P$. chrysospilos had shorter, thick, bent, and slightly twisted filaments (Fig. 1) in comparison to F. reichei that had longer, thin, and straight filaments (Fig. 2). Filaments of both species appeared to support secondary lamellae that are graded toward the tip.

Further investigation on the micrograph showed that there were about five secondary lamellae $(5.07 \pm 0.10$; $n=40)$ attached to $200-\mu \mathrm{m}$-long filament of $P$. chrysospilos (Fig. 3). However, there were about 10 secondary lamellae $(10.02 \pm 0.198 ; n=35)$ attached to $220-\mu \mathrm{m}$-long filament of $F$. reichei in similar dimension (Fig. 4). The gill rakers of the $P$. chrysospilos were slightly smaller, $(5.30 \pm 0.10$ rakers attached to $500-\mu \mathrm{m}$-long gill arch, $n=40)$ (Fig. 1) than that of $F$. reichei $(5.03 \pm 0.10$ rakers attached to 500- $\mu \mathrm{m}$-long gill arch, $n=35$ ) (Fig. 2). The secondary lamellae of the $P$. chrysospilos were triangular in shape and thick $(25-30 \mu \mathrm{m})$ which contained many apical pores and highly wrinkled (Figs. 3, 5). However, the secondary lamellae of the $F$. reichei were rectangular in shape, wavy, thin $(6-12 \mu \mathrm{m})$, contained no distinct apical pores, and smooth (Figs. 4, 6).

The skin epithelium of both fish species consisted of pavement and mucus cells. The pavement cells for P. chrysospilos were small pentagonal shape underlining with thick microridges and had double-ridged border in between the pavement cells (Figs. 7-9). These pavement cells had various microridges shape and size from 1 to 15 $\mu \mathrm{m}$ in length and 0.3 to $1.0 \mu \mathrm{m}$ in width (Figs. 7-9). The cells (Figs. 10-12) with rounded apical pores at the centre were mucus cells. These cells also had few microridges with the length vary from 2 to $5 \mu \mathrm{m}$. The microridges of the mucus cells were thick and elongate (Fig. 8). On the other hand, the pavement cells of $F$. reichei, seen as pentagonal or hexagonal shapes of irregular forms, consisted of a single microridges border in between pavement cells (Figs. 10-12). The pavement cell microridges also vary from 10 to $25 \mu \mathrm{m}$ in length and 0.2 to $0.6 \mu \mathrm{m}$ in width. The microridges inside the pavement cells were whorled and looked like a thumb print (Figs. 10-12).

\section{DISCUSSION}

The gills of Periophthalmus chrysospilos exhibit different features of morphology compared to Favonigobius reichei. The secondary lamellae of the former species decrease in size towards the filament tip. This will give an advantage to $P$. chrysospilos while they are on land by still exposing significant lamellae surface area for gaseous exchange even though if the lamellae are to coalesce upon terrestrial exposure (Low et al. 1988). However, the thick build-up of the secondary lamellae may contribute to the prevention of the juxtaposition of these lamellae towards each other while they are exposed to air.

Hughes and Datta Munshi (1979) reported that the thick lamellae in air-breathers act as an oxygen-conserving device or to prevent oxygen loss when the surrounding 

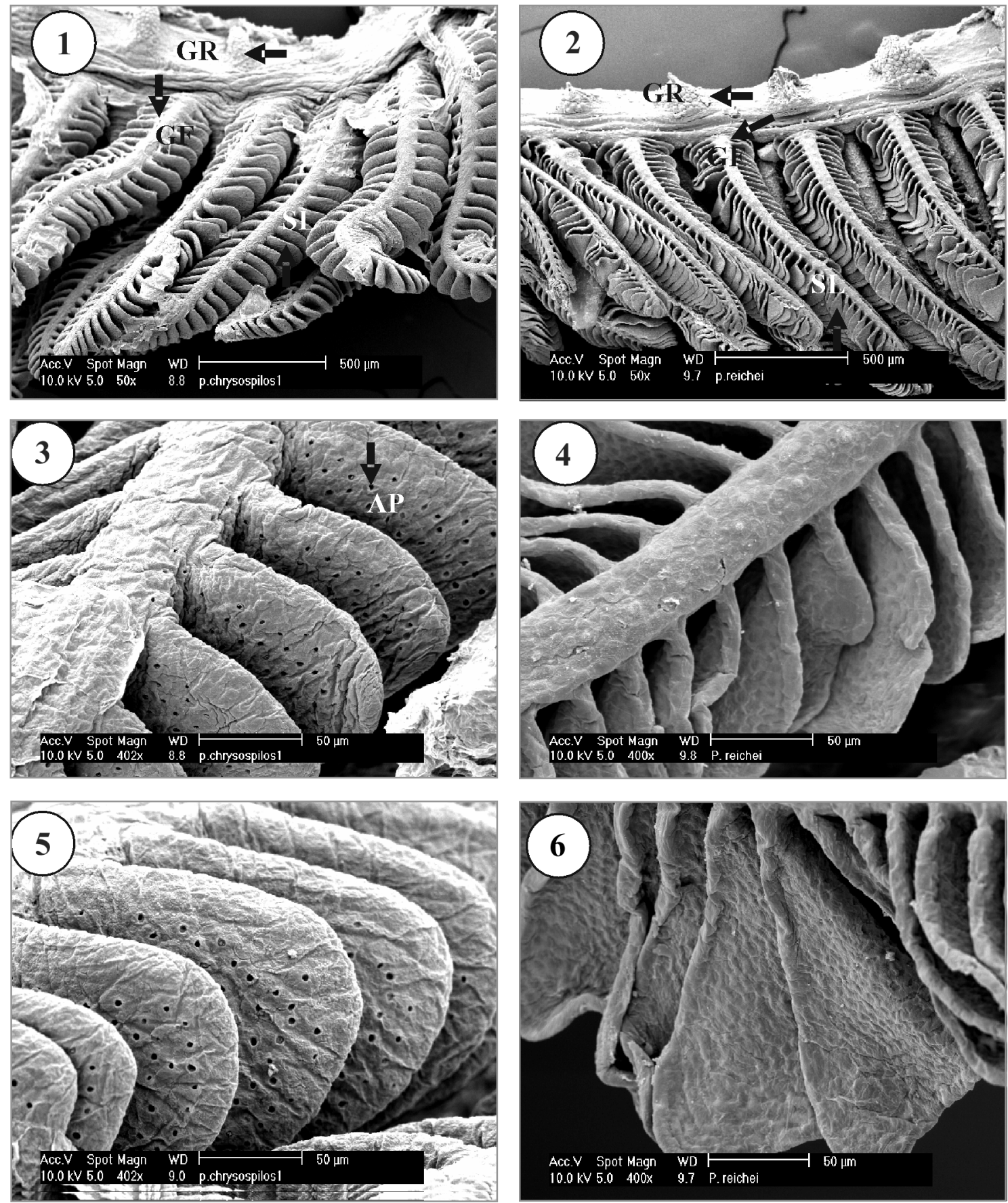

Figs. 1-6. Gills of Periophthalmus chrysospilos (Figs. 1, 3, 5) and Favonigobius reichei (Figs. 2, 4, 6) seen at various magnifications of SEM; Labels: GR, gill raker; GF, gill filament; SL, secondary lamellae; AP apical pores

water has low oxygen tension. Beside that, the secondary lamellae surfaces of $P$. chrysospilos are wrinkled that may increase the gill surface area. However, a problem that this mudskipper species faces during terrestrial exposure is that the gills may face the threat of desiccation. In order to prevent desiccation of the respiratory surface, the surface of the secondary lamellae may raise to function as a mucus-supporting tool (Morgan and Tovell 1973, Morris and Pickering 1975).

This mucus layer may work as an antidesiccant (Low et al. 1988). In addition, interposition of the mucus layer between the environment and epithelium suggests that the primary function of mucus is insulative in nature (Olson 1996). Many studies reported the functions of mucus as:

- physical barrier-preventing mechanical abrasion or deterrence of parasitic, bacterial, or viral access (Olson 1996),

- biochemical secretion-ability to precipitate specific molecules such as heavy metals (Olson and Fromm 1973, Varanasi and Markey 1978),

- immunological secretion-secretion of immunoglobulin (Ultsch and Gros 1979), and 

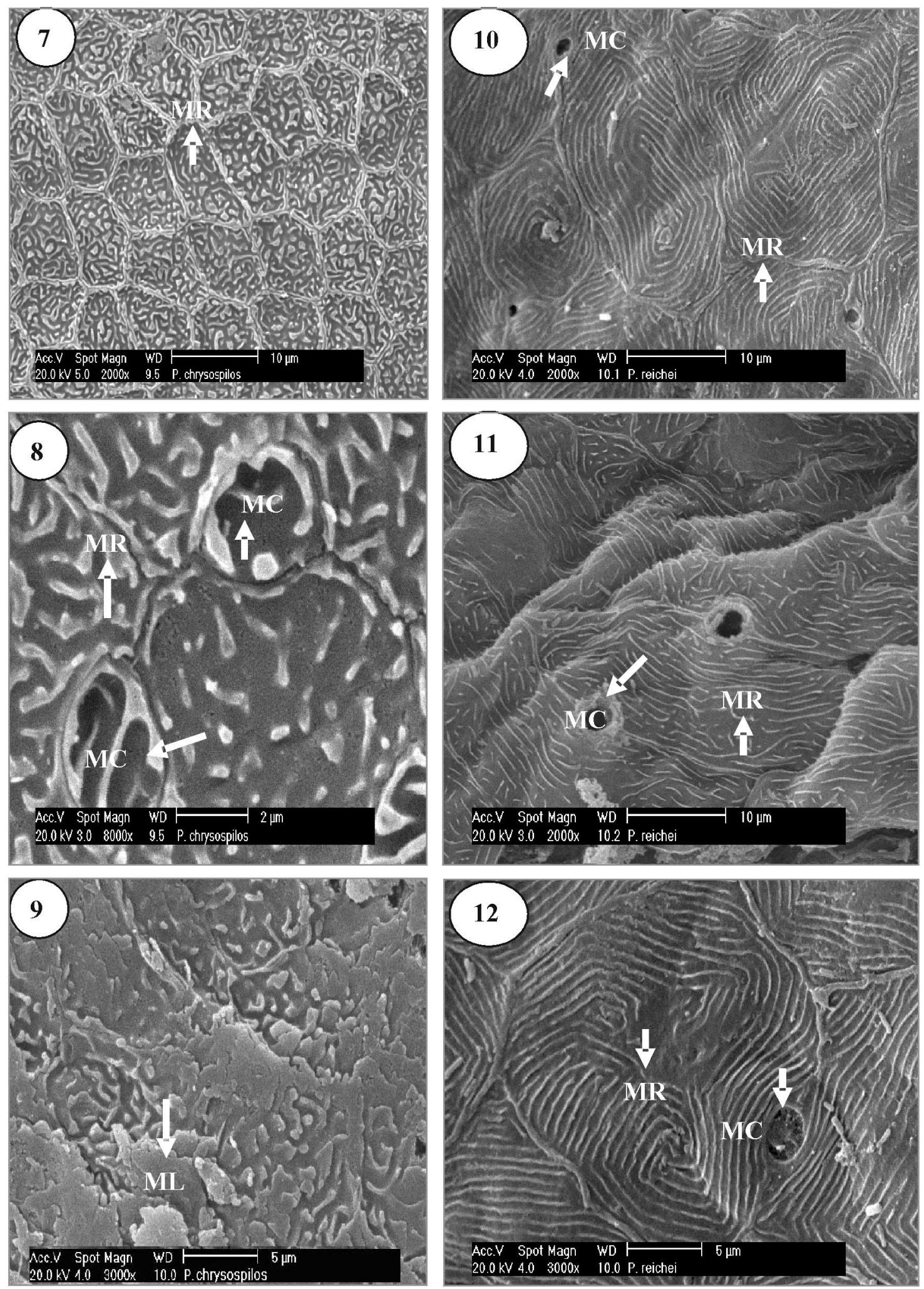

Figs. 7-12. Skin surface of Periophthalmus chrysospilos (Figs. 7, 8,9) and Favonigobius reichei (Figs. 10, 11, 12) seen at various magnifications of SEM; labels: MC, mucus cell; MR, microridge; ML, mucus layer

- electrolyte diffusion (ionic exchange) mechanism in the presence of chloride cells (Pärt and Lock 1983, Simonneaux et al. 1987, Handy 1989, Shephard 1994, Işsağ and Karakisi 1998).
In contrast, the bent and twisted filaments of $P$. chrysospilos are considered as disadvantage to this species when submerged in water. The twisted filaments may result in secondary lamellae not oriented parallel to the respirato- 
ry water current. Thus, it may reduce the efficiency of the counter-current distribution mechanism. On the other hand, such twisting filament orientation may help to keep filament apart in air and provide efficient air respiration for $P$. chrysospilos on land. The reductions of gill dimensions in air-breathing fishes are compensated by the development of some sort of accessory respiratory surfaces (Roy and Munshi 1996).

Among the oxudercine gobies, such as Periophthalmus, Boleophthalmus, and Scartelaos, the skin is vascularized, which helps in gas exchange (Low et al. 1988, Zhang et al. 2000, Park 2002). Thus, in P. chrysospilos, the skin fulfils the oxygen demand for some time when the moist surfaces for gas diffusion are available. Tamura et al. (1976) showed that oxygen uptake by the gills of $P$. cantonensis was $52 \%$ in water and $27 \%$ in air (of the total amount of oxygen respired). As its gills are inefficient in aquatic respiration, it would rather stay on land where its skin would be responsible for $76 \%$ of its oxygen uptake (Tamura et al. 1976, Yadav et al. 1990).

The surface skin structure of $P$. chrysospilos in the present study consisted of pavement and mucus cells. The mucus cells secreted mucus that is found scattered over the epithelium cells. The underlining microridges of pavement and mucus cells are raised and thickened. Several studies have proposed the function of microridges are to trap, hold or distribute mucus, provide structural integrity to the epithelium, or increase the surface area of the apical membrane (Olson and Fromm 1973, Sperry and Wassersug 1976, Low et al. 1990). The mucus on the gills and skin may have facilitated in reducing evaporative water loss and gas exchange (Olson 1996). The present study may indicate that the $P$. chrysospilos is able to breathe oxygen-using skin and it seems logical based on the presence of dense microridges on the skin surface.

On the other hand, F. reichei, which is a water-breathing fish, has different architectural plan of the gill apparatus compared to $P$. chrysospilos. F. reichei has gills that look homogenous and almost equal in size and shape except the fourth pair of gills that is slightly smaller. Since water is much denser and contains a very low concentration of oxygen per unit volume compared to air, F. reichei has large gill surface area for gas exchange to take place. The secondary lamellae of $F$. reichei are thin, broad, wavy, and densely packed towards the tip of the filaments which may enlarge the gill surface area (Figs. 2, 4, 6) - in contrast to $P$. chrysospilos that has much thicker lamella attached to filaments as an important adaptation to breath air (Figs. 1, 3, 5). F. reichei has buoyant support of water to solve the problem. The skin of $F$. reichei also has different architectural build up compared to $P$. chrysospilos. The surface structure of the skin is smooth underlining with thin microridges in the pavement cells and singleridged border in between pavement cells. In between the pavement cells, there are mucus cells distributed on the microridges. Since the skin of $F$. reichei may not actively involved in respiration, the function of microridges perhaps to provide structural integrity to the epithelium cells and mucus trapping devices. Knutton et al. (1976) proposed that microridges on Lettree cells allow rapid cell swelling without concomitant lysis, thereby allowing a change in cell size or shape without the need for membrane protein synthesis. In addition, Bereiter-Hahn et al. (1979) suggested that microridges on fish epidermal cells are attached to subcellular contractile elements and spontaneously change in size and appearance. Size and shape of epidermal microridges are also affected by ambient salinity, electrolytes and hormones (Schwerdtfeger 1979, Wendelaar Bonga and Meis 1981). The present of mucus cells over the epithelium cells of the skin of $F$. reichei would mainly function to secrete mucus. This mucus probably performs the same functions as discuss in $P$. chrysospilos except trapping the oxygen for cutaneous respiration.

\section{CONCLUSIONS}

The presence of low density of secondary lamellae and smaller gill rakers attached on the gill filaments and gill arch gave an advantage to $P$. chrysospilos living on land for extended periods of time in comparison to $F$. reichei that are more adapted to aquatic life by having higher density of secondary lamellae and larger gill rakers attached to the gill arch. Special architectural plan of gills and skins of both goby species may have contributed to their existence in the estuary area.

\section{ACKNOWLEDGEMENTS}

We would like to express our gratitude to Professor Dr. Atsushi Ishimatsu of Marine Research Institute, Nagasaki University for taking his precious time in reading and commenting this manuscript. This research was financially supported by the Ministry of Science and Technology of Malaysia through UKM-IRPA Grant No. 09-0202-0065-180EA.

\section{REFERENCES}

Al-Kadhomity N.K., Hughes G.M. 1988. Histological study of different regions of the skin and gills in the mudskipper, Boleophthalmus boddarti with respect to their respiratory function. Journal of Marine Biological Association of the United Kingdom 68: 413-422.

Bereiter-Hahn J., Osborn M., Weber K., Voth M. 1979. Filament organization and formation of microridges at the surface of fish epidermis. Journal of Ultrastructural Research 69: 316-330.

Handy R.D. 1989. The ionic composition of rainbow trout body mucus. Comparative Biochemistry and Physiology A 93: 571-575.

Hughes G.M., Morgan M. 1973. The structure of fish gills in relation to their respiratory function. Biological Reviews of the Cambridge Philosophical Society 48: 419-475.

Hughes G.M., Datta Munshi J.S. 1979. Fine structure of the gills of some Indian air-breathing fishes. Journal of Morphology 160: 169-193.

Işsağ S., Karakisi H. 1998. Fine structure of the chloride cell in the gill epithelium of Brachydanio rerio 
(Cyprinidae, Teleostei). Turkish Journal of Veterinary and Animal Sciences 22: 431-436.

Kottelat M., Whitten A.J., Kartikasari S.N., Wirjoatmodjo S. 1993. Freshwater fishes of Western Indonesia and Sulawesi. Periplus Editions, Jakarta.

Knutton S., Jackson D., Graham J.M., Micklem K.J., Pasternak C.A. 1976. Microvilli and cell swelling. Nature 262: 52-54.

Lee Y.J., Choi Y., Ryu B.S. 1995. A taxonomic revision of the genus Periophthalmus (Pisces: Gobiidae) from Korea with description of a new species. Korean Journal of Ichthyology 7: 120-127.

Low W.P., Ip Y.K., Lane D.J.W. 1990. A comparative study of the gill morphometry in the mudskippers Periophthalmus chrysospilos, Boleophthalmus boddaerti and Periophthalmodon schlosseri. Zoological Science 7: 29-38.

Low W.P., Peng K.W., Phuan S.K., Lee C.Y., Ip Y.K. 1993. A comparative study on the responses of the gills of two mudskippers to hypoxia and anoxia. Journal of Comparative Physiology B 163: 487-494.

Low W.P., Lane D.J.W., Ip Y.K. 1988. A comparative study of terrestrial adaptations of the gills in three mudskippers-Periophthalmus chrysospilos, Boleophthalmus boddaerti, and Periophthalmodon schlosseri. Biological Bulletin 175: 434-438.

Morgan M., Tovell P.W.A. 1973. The structure of the gill of the trout, Salmo gairdneri (Richardson). Zeitschrift für Zellforschung 142: 147-162.

Morris R., Pickering A.D. 1975. Ultrastructure of the presumed ion-transporting cells in the gills of ammocoete lampreys, Lampetra fluviatilis (L.) and Lampetra planeri (Bloch). Cell and Tissue Research 163: 327-341.

Murdy E.O. 1989. A taxonomic revision and cladistic analysis of the oxudercine gobies (Gobiidae: Oxudercinae). Records of the Australia Museum. Supplement (11): 1-93.

Murdy E.O., Takita T. 1999. Periophthalmus spilotus, a new mudskipper from Sumatra (Gobiidae: Oxudercinae). Ichthyological Research 46: 367-370.

Nelson J. 1994. Fishes of the World. 3rd edn. John Wiley and Sons, New York.

Olson K.R. 1996. Scanning electron microscopy of the fish gill. Pp. 31-45. In: Munshi J.S.D., Dutta H.M (eds.) Fish morphology: Horizon of New Research. Science Publishers, Enfield, USA.

Olson K.R., Fromm P.O. 1973. Mercury uptake and ion distribution in gills of rainbow trout (Salmo gairdneri): Tissue scans with an electron microprobe. Journal of the Fisheries Research Board of Canada 30: 1575-1578.

Park J.Y. 2002. Structure of the skin of an air-breathing mudskipper fish, Periophthalmus magnuspinnatus. Journal of Fish Biology 60: 1543-1550.

Park J.Y., Lee Y.J. 2002. On structure of epidermis of an amphibious mudskipper, Boleophthalmus pectini- rostris (Pisces: Gobiidae). Korean Journal of Ichthyology 14: 1-7.

Pärt P., Lock R.A.C. 1983. Diffusion of calcium, cadmium and mercury in a mucous solution from rainbow trout. Comparative Biochemistry and Physiology $\mathbf{C}$ 76: 259-263.

Roy P.K., Munshi J.S.D. 1996. Morphometrics of the respiratory system of air-breathing fishes of India. Pp. 203-230. In: Munshi J.S.D., Dutta H.M. (eds.) Fish morphology: Horizon of new research. Science Publishers, Enfield, USA

Sayer M.D.J. 2005. Adaptations of amphibious fish for surviving life out of water. Fish and Fisheries 6 (3): 186-211.

Schwerdtfeger W.K. 1979. Morphometrical studies of the ultrastructure of the epidermis of the guppy, Poecilia reticulata Peters, following adaptation to seawater and treatment with prolactin. General and Comparative Endocrinology 38: 476-483.

Shephard K.L. 1994. Functions for fish mucus. Review in Fish Biology and Fisheries 4: 401-429.

Simonneaux V., Humbert W., Kirsch R. 1987. Mucus and intestinal ion exchange in the sea-water adapted eel, Anguilla anguilla L. Journal of Comparative Physiology B 157: 295-306.

Sperry D.G., Wassersug R.J. 1976. A proposed function for microridges on epithelial cells. The Anatomical Record 185: 253-258.

Suzuki N. 1992. Fine structure of the epidermis of the mudskipper, Periophthalmus modestus (Gobiidae). Japanese Journal of Ichthyology 8: 379-396.

Takita T., Agusnimar, Ali A.B. 1999. Distribution and habitat requirements of oxudercinae gobies (Gobiidae:oxudercinae) along the Straits of Malacca. Ichthyological Research 46: 131-138.

Tamura S.O., Morii H., Yuzuriha M. 1976. Respiration of the amphibious fishes Periophthalmus cantonensis and Boleophthalmus chinensis in water and on land. Journal of Experimental Biology 65: 97-107.

Ultsch G.R., Gros G. 1979. Mucus as diffusion barrier to oxygen: Possible role in $\mathrm{O}_{2}$ uptake at low $\mathrm{pH}$ in carp (Cyrinus carpio) gills. Comparative Biochemistry and Physiology A 62: 685-689.

Varanasi U., Markey D. 1978. Uptake and release of lead and cadmium in skin and mucus of coho salmon (Oncorhynchus kisutch). Comparative Biochemistry and Physiology C 60: 187-191.

Wendelaar Bonga S.E., Meis S. 1981. Effects of external osmolality, calcium and prolactin on growth and differentiation of the epidermal cells of the cichlid teleost Sarotherodon mossambicus. Cell and Tissue Research 221: 109-123.

Wilson J.M., Kok T.W.K., Randall D.J. Vogl W.A., Ip K.Y. 1999. Fine structure of the gill epithelium of the terrestrial mudskipper, Periophthalmodon schlosseri. Cell and Tissue Research 298: 345-356.

Whitear M. 1986. The skin of fishes including cyclostomes: epidermis. Pp. 9-64. In: Bereiter-Hahn J., 
Matoltsy A.G., Richards K.S. (eds.) Biology of the integument. Vol. 2, Vertebrates. Springer-Verlag, Berlin and New York.

Yadav A.N., Prasad M.S., Singh B.R. 1990. Gross structure of the respiratory organs and dimensions of the gill in the mud-skipper, Periophthalmus schlosseri (Bleeker). Journal of Fish Biology 37: 383-392.

Yokoya S., Tamura S.O. 1992. Fine structure of the skin of the amphibious fishes, Boleophthalmus pectinirostris and Periophthalmus cantonensis, with special reference to the location of blood vessels. Journal of Morphology 214: 287-297.
Zhang J., Taniguchi T., Takata T., Ali A.B. 2000. On the epidermal structure of Boleophthalmus and Scartelaos mudskippers with reference to their adaptation on terrestrial life. Ichthyological Research 47: 359-366.

Received: 13 October 2006

Accepted: 2 February 2007

Published electronically: 15 February 2007 